\title{
Political Cycles in the Australian Stock Market since Federation
}

\author{
Andrew C. Worthington ${ }^{*}$ \\ Griffith Business School, Griffith University
}

\begin{abstract}
This paper examines the political cycle in Australian stock returns from 1901 to 2005. We define the political cycle in terms of the party in power, ministerial tenure and election information effects. The market variables are returns, excess returns over inflation and excess returns over interest rates. Descriptive analysis suggests differences in the variance of returns under Labor and non-Labor ministries, but no significant differences in mean returns. Using GARCH-M, returns are found to be only higher for non-Labor ministries before 1949 and there is no difference in excess returns over inflation or interest throughout the full sample.
\end{abstract}

\section{Introduction}

Anecdotal evidence abounds of the link between securities markets and politics. In the financial media, most economic and social policy is scrutinized concerning possible market reactions, while industry and consumer groups comment on anticipated and hoped for changes in policy. At election time, politicians are frequently accused of pork-barrelling, with firms and investors alike anticipating the heady mix of tax breaks, consumption and production subsidies, and fiscal and monetary stimulation that accompanies changes in the political party in power. At the same time, parties are routinely pigeon-holed as pro- or antibusiness and pro- or anti-investor, reflected in some way in the flow and source of political donations.

At least three empirical questions arise from such observations. First, does market behaviour differ when governments are drawn from different political parties? That is, is stated ideology reflected in actual policy, and does this systematically vary in its influence on market participants. Second, is this political influence constant or changing with the ebb and flow of mandated terms in office and efforts to secure re-election? Put differently, is ideology of any form implemented in a different way in business and investor policy at the beginning of terms of an office that at the end? Finally, do markets react to unexpected election results? That is, if we assume that current stock prices fully incorporate political information under the efficient markets hypothesis, does the presence of electoral surprises constitute a violation of 
semi-strong form market efficiency and therefore an opportunity for the earning of abnormal profits?

Clearly, these are important concerns, thereby motivating the present study. First, the presence of a political cycle in returns may help strengthen a particular political party's claim to better economic management, and thereby improving its prospects for electoral success. Second, the presence of a political cycle may aggravate some aspects of the business cycle, thereby comprising an additional concern for economic policymakers. Finally, there is little work on political cycles in Australia, and this study therefore provides evidence from a different economic and political milieu to complement the (primarily) US literature.

The purpose of this paper is to add to this intriguing body of work the results of an analysis of the Australian federal political cycle and its impact on the Australian equity market. The paper itself is divided into four main areas. Section 2 briefly reviews the relevant literature. Section 3 explains the data collection employed and presents the empirical methodology. Section 4 presents the results. The paper ends with a brief conclusion and some directions for future research.

\section{Previous Findings}

There are two strands of research in the analysis of political cycles. The first strand concerns institutional rigidities in the political cycle, like mandated terms in office, and the structure they impose upon market returns. This also includes the effects of elections and similar activities on market behaviour. For the most part, much of this research has been in the US context. Herbst and Slinkman (1984), for instance, examined the period from 1926 to 1977 and found a 48-month cycle during which returns were higher than average, peaking in November during the presidential elections. Likewise, Huang (1985) used data from 1832 to 1979 and discovered that stock returns were systematically higher in the last half of a political term than in the first, as did Hensel and Ziemba (1995). On this basis, Hensel and Ziemba (1995, p. 67) suggested ' ...these findings are consistent with the hypothesis that political reelection campaigns create policies that stimulate the economy and are positive for stock returns'.

In the United Kingdom, Manning (1989) showed that British Telecom shares, though not

\footnotetext{
* The author would like to thank two anonymous referees, the editor (Ross Williams), seminar participants at Griffith University and the University of Canberra, and delegates at the $19^{\text {th }}$ Australasian Finance and Banking
} 
the market as a whole, reacted to opinion polls surrounding the 1987 General Election in the face of impending nationalisation. Likewise, Peel and Pope (1983), Gwilym and Buckle (1984) and Thompson and Ioannidis (1987) examined the connection between the stock market and business support for Tory (Conservative) governments. But most recently, Hudson et al. (1998) found that while short-term price movements reacted to opinion polls in the run-up to and including elections, there was no statistically significant evidence of a difference in nominal or real returns between Tory and Labour governments. In general, most recent research in the US, including Ferri (2008) and Bohl et al. (2008), and elsewhere, see Li and Born (2006), Beaulieu et al. (2005, 2006) and Lim et al. (2008), confirm that elections and other political events have short-term impacts on markets.

However, the second and larger strand of research on political cycles focuses on differences in political ideology and their impact on stock returns. Herein the focus of interest is on the apparent preference of the market, especially in the US, for right-of-centre presidents (i.e. Republicans). In seminal work, Niederhoffer et al. (1970) showed that US stock market movements around election dates were consistent with a pro-Republican bias on Wall Street, though evidence was not forthcoming on any longer-term relationship. Similarly, Riley and Luksetich (1980) concluded that the market prefers Republicans and tends to rise following presidential elections. Dobson and Dufrene (1993) extended this analysis outside of the United States, concluding that in equity market terms US presidential elections invoke significant structural changes, with international markets becoming more highly correlated. Other studies concerning the posited positive market effect of Republican presidencies have been undertaken by Hobbs and Riley (1984), Foerster and Schmitz (1997), Johnson and Chittenden (1999) and Booth and Booth (2003).

Most recently, and of most relevance to the present study, Santa-Clara and Valkanov (2003) re-examined the 'presidential puzzle' sometimes arising in this research: that is, real returns are higher under Democratic presidents, contradicting the conventional wisdom that Republicans are good for markets in a manner unexplained by considerations of risk. Using data since 1927, Santa-Clara and Valkanov (2003) found average excess returns for valueweighted market indexes over three-month Treasury bills of about 2 per cent under Republicans and 11 per cent under Democrats. Further, a decomposition of returns revealed that the difference was due to real market returns being 5 per cent higher under Democrats 
and real interest rates almost 4 per cent lower. Responding to the question of whether the difference in average returns was due to a difference in expected (a Democratic risk premium) or unexpected (surprises in the economic policies of the party in the presidency) returns, Santa-Clara and Valkanov (2003) concluded that presidential parties capture variations in returns that are largely uncorrelated to what is explained by business cycle fluctuations. Hence, they must be associated with systematic differences in political policies.

However, in a critique of Santa-Clara and Valkanov (2003), Powell et al. (2007) argue that because dichotomous explanatory variables can be highly persistent in time series regressions, these findings may be spurious. By regressing simulated stock market returns against an independently generated presidential regime dummy variable series, and extending the sample in Santa-Clara and Valkanov (2003) back to the mid-1800s, when the differences between Republicans and Democrats became clearer, Powell et al. (2007) find lower adjusted $\mathrm{R}^{2}$ and coefficient estimates in presidential regime return differences than would be expected by chance. This suggests that the US presidential regime differences found in previous studies, including Santa-Clara and Valkanov (2003), are insignificant.

There has also been only some work in this vein elsewhere. In New Zealand, Cahan et al. (2005) concluded that the presidential puzzle reversed, and that New Zealand market returns were lower under left-leaning Labour governments than under National governments. Lastly, Anderson et al. (2008) examined the political cycle in bond, property and stock markets in Australasia using monthly returns. They found no particular political cycle in bond returns, but concluded that real equity returns were higher under right-leaning governments because of lower inflation.

\section{Empirical Methodology}

\subsection{Data and Variable Specification}

Table 1 provides details of the 59 Australian federal ministries from Federation on 1 January 1901 until December 2005. All information is from the Australian Electoral Commission (2008a, 2008b, 2008c). We define each ministry as either Labor or non-Labor. The Australian Labor Party is Labor and non-Labor are all other ministries (including the Protectionist, Free

suggestions on an earlier version of this paper. 
Trade, Tariff Reform, Nationalist Labour, Nationalist, United Australia, Country, Country Liberal, National, and Liberal parties)

We define the political cycle variables using this information. The four political cycle variables are as follows. To start with, two dummy variables are specified that take a value of one for months non-Labor is in power and zero otherwise $\left(N L_{t}\right)$, while the second takes a value of one if the Labor Party is in power and zero otherwise $\left(L_{t}\right)$ (the model specified later does not contain a pure constant term). The next two political variables are included to take account of whether the return on equities varies across the term in office. This follows suggestions by Herbst and Slinkman (1984), Huang (1985) and Hensel and Ziemba (1995) that the policy cycle followed by governments in power stimulates the economy and is reflected in market returns. Rather than using dummy variables to identify whether a day falls in, say, the first or second half of the period in office as in Hudson et al. (1998), a continuous variable $\left(T_{t}\right)$ is specified as a simple linear trend taking a value of one on the first month in office, two on the second month, and so on. This variable is reset at the beginning of the next ministries' term in office. A fourth dummy variable takes a value of one for months that include an election and zero otherwise $\left(E_{t}\right)$. We hypothesize that this variable helps capture the impact of election results on market returns in the same spirit as an event study. Importantly, the election dummy should only pick up election surprises where there is an unexpected change in government.

\section{$<$ TABLE 1 HERE $>$}

The market data employed are end-of-month closing prices from the Australian Securities Exchange (ASX) and its predecessors over the period January 1901 to December 2005. This sample encompasses 1,258 months [daily data is available, but only since 1958]. The capitalization-weighted All Ordinaries Price Index is used. The index is from Global Financial Data (2008), a specialist provider of historical financial market information [see the provider's website for details of the construction of the index]. One problem is that an accumulation index (including both price changes and income) is unavailable that would better reflect total equity returns over the entire sample period. While an accumulation index was calculated for the Sydney Stock Exchange from July 1980 and a stock accumulation index for 1882-1979 was constructed retrospectively in the mid-1980s using price index data and three historical dividend yield series, it is only quarterly (Brailsford et al. 2008). 
Brailsford et al. (2008) provide a detailed analysis of historical equity accumulation returns in Australia from 1883 to 2005 that elaborates on these and other issues.

A series of monthly market returns $R_{t}=100 \ln \left(P_{t} / P_{t-1}\right)$ are first calculated where $P_{t}$ is the index level at the end of month $t$. Table 1 includes the mean return by ministry. Two measures of excess return are also calculated following Santa-Clara and Valkanov (2003). The first is the difference between the monthly market return and the monthly inflation rate as represented by the Australian consumer price index $\left(R_{t}-I_{t}\right)$. The second is the difference between the monthly market return and the monthly return on an Australian three-month Treasury bill $\left(R_{t}-Y_{t}\right)$ [these have only been issued since July 1928]. Both the inflation and interest rate series are also from Global Financial Data (2008). The mean monthly excess return over inflation and excess return over interest by ministry are also included in Table 1.

\subsection{Descriptive Analysis}

Figure 1 plots the mean monthly return by ministry. As shown, mean monthly returns (ministry in brackets) are highest during Holt (35) (non-Labor), Hawke (50) (Labor) and Fraser (44) (non-Labor) and lowest during Page (19) (non-Labor), Whitlam (42) (Labor) and Fraser (47) (non-Labor). Returns range between -2.35 and 4.75 per cent with an average monthly return of 0.49 per cent (or 6.05 per cent per year over the full sample period). Excess returns over inflation range between -3.24 and 2.85 per cent, with a monthly average of 0.16 per cent or 1.8 per cent per year. Over the period 1901-2005, inflation averaged 0.33 per cent per month and 4.10 per cent per year. Excess returns over interest rates range between -3.24 and 2.85 per cent monthly. The average monthly excess return over interest is 0.06 per cent equating to 0.7 per cent per year. Over the shorter period 1928-2005, interest rates as defined averaged 0.43 per cent per month and 5.32 per cent per year.

\section{$<$ FIGURE 1 HERE $>$}

Table 2 includes descriptive statistics by Labor and non-Labor ministries for returns, excess returns over inflation and excess returns over interest rates. As shown, mean returns are higher for non-Labor (0.57) than Labor (0.31), as are excess returns over inflation $(0.26$ and -0.09 , respectively) and excess returns over interest rates ( 0.20 and -0.22 , respectively). The respective volatility of returns (as measured by standard deviation) is higher for Labor than non-Labor (5.22 and 3.28 for returns, 5.28 and 3.33 for excess returns over inflation and 
5.70 and 3.73 for excess returns over interest rates). This would indicate that all three measures of market return are lower and more uncertain under Labor ministries than nonLabor ministries. Tests for equality of means and variances fail to reject the null hypothesis of equality of means for Labor and non-Labor ministries, but do reject the null hypotheses for the equality of variances.

\section{$<$ TABLE 2 HERE $>$}

By and large, the distributional properties of the nominal returns series during ministries appear non-normal. Returns (-2.10), excess returns over inflation $(-2.24)$ and excess returns over interest (-2.23) are significantly negatively skewed. Interestingly, the degree of skewness for non-Labor ministries is always less than Labor ministries. The kurtosis across is mostly large, indicating leptokurtic distributions with many extreme observations for returns (29.55), excess returns over inflation (34.24) and excess returns over interest (30.20). However, once again the degree of kurtosis for non-Labor ministries is always less than during Labor ministries. Clearly, returns during Labor ministries have more volatile, extreme and negative values than comparable non-Labor ministries. Finally, the Jarque-Bera statistics reject the null hypotheses of normality at the .01 level for all series.

\subsection{Model Specification}

The descriptive analysis of Australian market returns is suggestive of non-normality and autoregressive conditional heteroskedastistic (ARCH) behaviour. More formally, Lagrange multiplier tests in Table 3 fail to reject the null hypothesis of no ARCH errors. Accordingly, following Brooks and Henry (2000), Brooks et al. (2001), Mian et al. (2001), Kim and In (2002), and Worthington (2006, 2008) and others on the suitability of generalized ARCH (GARCH) modelling in the Australian stock market, a $\operatorname{GARCH}(p, q)-\mathrm{M}$ model used is employed as follows: 


$$
\begin{aligned}
& r_{s, t}=\alpha_{s, k} \sum_{k=1}^{n} x_{s, k}+\gamma_{s, 0} h_{s, t}+\varepsilon_{s, t} \\
& h_{s, t}=\beta_{s, 0}+\beta_{s, i} \sum_{i=1}^{p} \varepsilon_{s, t-i}^{2}+\gamma_{s, j} \sum_{j=1}^{q} h_{s, t-j} \\
& \varepsilon_{s, t} \mid \Omega_{s, t-1} \sim N\left(0, h_{s, t}\right)
\end{aligned}
$$

where $r_{s, t}$ is the market return at time $t$ ( $s=R_{t}, R_{t}-I_{t}$ and $R_{t}-Y_{t}$ ), $x_{s, k}$ are the set of $k$ political factors that influence $r_{s, t}\left(x=N L_{t}, L_{t}, T_{t}\right.$ and $\left.E_{t}\right), h_{s, t}$ is the return volatility of the market portfolio $s$ at time $t$, and $\varepsilon_{s, t}$ is a normally distributed error term with zero mean and a variance of $h_{s, t}$. The sensitivity of the market portfolio $s$ at $t$ to the political factors is measured by the $n$ parameters of $\alpha_{s, k}$. The conditional variance $h_{s, t}$ follows (2) and for the sth market portfolio is determined by the past squared error terms $\left(\varepsilon_{t-1}^{2}\right)$ and past behavior of the variance $\left(h_{t-1}\right), \beta s, 0$ is the time-invariant component of risk for the sth market portfolio, $\beta s_{i l}$ are the ARCH parameter(s) and $\gamma_{s, j}$ are the GARCH parameter(s).

\section{Empirical Results}

The estimated coefficients and standard errors for the conditional mean return and variance equations are presented in Table 3. Different GARCH-M $(p, q)$ models (not shown) were initially fitted to the data and compared on the basis of the Akaike and Schwarz Information Criteria from which a GARCH(1,1) model was deemed most appropriate for modelling the monthly return process for the market returns.

The estimated coefficients, standard errors and p-values of the GARCH-M(1,1) parameters are presented in Table 3. Nine separate models with three different dependent variables across three different sample periods are estimated: returns (columns 4, 5 and 6) $\left(R_{t}\right)$, excess returns over inflation (columns 7, 8 and 9) $\left(R_{t}-I_{t}\right)$ and excess returns over interest rates (columns 10, 11 and 12) $\left(R_{t}-Y_{t}\right)$ and the full sample from January 1901 to December 2005 (uppermost panel), another from January 1901 (July 1928 for excess returns over interest rates) to December 1949 (middle panel) and a further from January 1950 to December 2005 (lower panel). The breakpoint for splitting the sample is somewhat arbitrary, but does divide the sample into two fairly equal periods, and takes allowance of the post-war shift from Labor to the more than twenty year dominance of non-Labor.

$<$ TABLE 3 HERE $>$ 
The political cycle hypotheses are tested as follows. As a rule, the market return for nonLabor governments is expected to be higher than the market return for Labor governments. Moreover, it is hypothesized that returns vary within a given ministerial term, such that returns may increase or decline during the term of office. Further, it is hypothesized that returns in a month when an election is held may be higher or lower than returns during the same political term, but the direction may be dependent upon whether the election comprises a shock. Santa-Clara and Valkanov (2003: 1863), for example, argued that “...if the observed difference in returns is due to a difference in expected returns, the change in the level of the market at the time that the information is revealed should be quite large”. Two hypotheses are tested. The first is a test of the joint hypothesis that all four political parameters are significant in influencing market returns $\left(\mathrm{H}_{\mathrm{N}}: \alpha_{1}+\alpha_{2}+\alpha_{3}+\alpha_{4}=0 ; \mathrm{H}_{\mathrm{A}}: \alpha_{1}+\alpha_{2}+\alpha_{3}+\alpha_{4} \neq 0\right)$ the second is that the estimated coefficient on non-Labor is equal to the estimated coefficient for Labor $\left(\mathrm{H}_{\mathrm{N}}: \alpha_{1}=\alpha_{2} ; \mathrm{H}_{\mathrm{A}}: \alpha_{1}>\alpha_{2}\right)$. If the first null hypothesis is rejected, then market returns exhibit a form of political cycle, related to either the party in power and/or the tenure of power and/or election effects. If we reject the second, then the parties have a differential impact upon market returns. While these tests are not in Santa-Clara and Valkanov (2003) (the study most like the present analysis), it is clearly appropriate to formally test the political cycle parameters.

All of the models in Table 3 are highly significant, with tests rejecting the null hypotheses of joint insignificance of the four political cycle variables at the .01 level. Starting with the period 1901-2005 (upper panel), the coefficient on non-Labor is always significant and positive and higher than Labor for returns, excess returns over inflation and excess returns over interest rates. However, only in the case of returns does a Wald test reject the null hypothesis of equality for the non-Labor and Labor coefficients in favour of the alternative hypothesis that the coefficient for non-Labor is greater than Labor.

In the earlier subsample period 1901/1928-1949 (middle panel) the coefficient for nonLabor is significantly positive for returns and excess returns over inflation, but not excess returns over interest rates. The coefficient for Labor is only significant in the model where returns are specified as the dependent variable. It is also only this model where the Wald test indicates that the difference in returns between the parties lie in favour of non-Labor governments. This provides some support for the contention that right-of-centre (i.e. nonLabor) governments are better for investors and there is no evidence of the presidential puzzle 
found in the US. However, given that there is no significant difference in excess returns over inflation or interest rates during this period, it would also suggest that the equity premium is unaffected by change in the political party in power, and that the higher returns under nonLabor governments are offset, on average, by higher inflation and/or interest rates.

After 1950 while the return and excess returns over inflation coefficients for both nonLabor and Labor governments are significant, and the coefficients for Labor are higher, they are not significantly different from each other. Excess returns over interest rates are positive and significant for non-Labor, but are not significantly different from the Labor coefficient. This supports an opinion that the differences between these party's ideologies in terms of their economic credentials have become less in recent decades. In particular, the market-friendly financial reforms and rightward shift in social policy made under the Hawke/Keating governments in the 1980s served to remove at least some business and investor concerns regarding Labor governments.

For the remaining coefficients, the coefficient for the term in office is always negative, but never significant, while the coefficient for election months is always positive and significant, indicating that returns are higher during months in which an election is held. This suggests that elections are always seen as having positive market impact, though it is unclear whether this from the stimulative effects of the policy promises made to secure election or re-election, or from the generally positive market impact of a democratic transition or retention of power and the removal of uncertainty. In none of the models is the variance term $(\gamma)$ in the mean equation significantly negative. While a GARCH-M model is useful in that it allows a (positive) variance term to be included in the mean equation, as found in asset pricing models, the relationship between return and volatility in models like this is far from clear empirically. However, in the return and excess return over inflation models in the upper panel (the full sample period), the conditional variance process is mildly explosive $\left(\beta_{1}+\gamma_{1}>1\right)$. This is suggestive of model misspecification and likely in a model encompassing only a small set of political cycle parameters.

\section{Conclusion}

The present study employs a number of different procedures to test for a political cycle in the Australian stock market since Federation in January 1901. To start with, descriptive analysis indicates that while there are statistically significant differences in the variances of monthly 
returns under non-Labor and Labor governments there are no statistically significant differences in mean returns, regardless of whether they are defined in terms of returns, excess returns over inflation or excess returns over interest. Modeling the political cycle using ARCH techniques is only marginally suggestive of higher returns under non-Labor ministries, but only for returns and not excess returns, and primarily only for the period before December 1949. The former indicates that much of the difference between different political parties ties up with macroeconomic factors such as interest rates, and reflects the opinion that political risk is mostly reflected in these rather than stock returns. From 1950 onwards, there is no significant difference between the parties and this suggests that any pro- or anti-bias by business and/or investors has lessened in recent decades. This is consistent with a rightward shift in economic and social policy by the Labor party, especially during the 1980s. On balance, there is accordingly almost no evidence of a political cycle in the Australian stock market.

Of course, this study does suffer a number of limitations, all of which suggest future avenues for research. First, it has not been possible to distinguish between small and large caps in the Australian market. Hensel and Ziemba (1995), for example, identified that while the returns of large caps were identical under different administrations in the US, a significant small cap effect existed under Democratic presidencies. Second, the monthly sampling frequency employed in this study means that many interesting aspects of the political cycle could not be fully addressed. More frequent sampling (i.e. daily) would nevertheless direct attention to the information effects of elections and election outcomes in the spirit of an event study [see, for instance, Santa-Clara and Valkanov (2003)]. Third, the model employed is very simple and there is no attempt to allow for other factors influencing returns, including global market conditions, commodity prices, price controls and other regulations. This may help explain the differences in return variances between Labor and non-Labor. Finally, there is the problem of endogeneity. The literature basically argues that political factors determine market returns. However, it is also possible (and rather likely) that market conditions determine which government is elected and how long it remains in power. This requires further inquiry including statistical procedures and alternative methodologies. 


\section{References}

Anderson, H. D. Malone, C. B. and Marshall, B. R. 2008, 'Investment returns under rightand left-wing governments in Australasia', Pacific-Basin Finance Journal, vol. 16, pp. 252-67.

Australian Electoral Commission 2008a, Election Dates (1901 to Present), viewed April 2008 $<$ http://www.aec.gov.au/Elections/Australian_Electoral_History/hor_dates.htm>.

Australian Electoral Commission 2008b, Electoral Pocketbook 2007, viewed April 2008 $<$ http://www.aec.gov.au/About_AEC/Publications/electoral_pocketbook/2007.htm>.

Australian Electoral Commission 2008c, Prime Ministers and Opposition Leaders, viewed April $2008<$ http://www.aec.gov.au/Elections/Australian_Electoral_History/pm.htm>.

Beaulieu, M. C. Cosset, J. C. and Essaddam, N. 2005, 'The impact of political risk on the volatility of stock returns: The case of Canada', Journal of International Business Studies, vol. 36, pp. 701-18.

Beaulieu, M. C. Cosset, J. C. and Essaddam, N. 2006, 'Political uncertainty and stock market returns: Evidence from the 1995 Quebec Referendum', Canadian Journal of Economics, vol. 39, pp. 621-41.

Bohl, M. T. Dopke, J. and Pierdzioch, C. 2008, 'Real-time forecasting and political stock market anomalies: Evidence for the United States', Financial Review, vol. 43, pp. 323-35.

Booth, J. R. and Booth, L. C. 2003, 'Is the presidential cycle in security returns merely a reflection of business conditions?', Review of Financial Economics, vol. 12, pp. 131-59.

Brailsford, T. Handley, J. C. and Maheswaran, K. 2008, 'Re-examination of the historical equity risk premium in Australia’, Accounting and Finance, vol. 48, pp. 73-97.

Brooks, C. and Henry, U. T. 2000, 'Linear and non-linear transmission of equity return volatility: Evidence from the US, Japan and Australia’, Economic Modelling, vol. 17, pp. 497-513.

Brooks, R. D. Faff, R. W. and Fry, T. R. L. 2001, GARCH modelling of individual stock data: The impact of censoring, firm size and trading volume, Journal of International Financial Markets, Institutions and Money, vol. 11, pp. 215-22.

Cahan, J. Malone, C. B. Powell, J. G. and Choti, U. W. 2005, 'Stock market political cycles in a small, two-party democracy’, Applied Economics Letters, vol. 12, pp. 735-40.

Dobson, J. and Dufrene, U. B. 1993, 'The impacts of U.S. presidential elections on international security-markets', Global Finance Journal, vol. 4, pp. 39-47.

Ferri, M. G. 2008, 'The response of US equity values to the 2004 presidential election', Journal of Applied Finance, vol. 18, pp. 29-37.

Foerster, S. R. and Schmitz, J. J. 1997, 'The transmission of US election cycles to international stock returns', Journal of International Business, vol. 28, pp. 1-27.

Global Financial Data 2008, viewed April 2008, <http://www.globfindata.com>.

Gwilym, O. A. P. and Buckle, M. 1994, 'The efficiency of stock and options markets: Tests based on 1992 UK election opinion polls', Applied Financial Economics, vol. 4, pp. 34554.

Hebst, A. F. and Slinkman, C. W. 1984, 'Political-economic cycles in the US stock market', Financial Analysts Journal, vol. 40, pp. 38-44.

Hensel, C. R. and Ziemba, W. T. 1995, 'United States investment returns during Democratic and Republican Administrations, 1928-1993’, Financial Analysts Journal, vol. 51, pp. 6169. 
Hobbs, G. R. and Riley, W. B. 1984, 'Profiting from a presidential election', Financial Analysts Journal, vol. 40, pp. 46-52.

Huang, R. D. 1985, 'Common stock returns and presidential elections', Financial Analysts Journal, vol. 41, pp. 58-65.

Hudson, R. Keasey, K. Dempsey, M. 1998, Share prices under Tory and Labour governments in the UK since 1945', Applied Financial Economics, vol. 8, pp. 389-400.

Johnson, R. R. and Chittenden, W. 1999, 'Presidential politics, stocks, bonds, bills, and inflation', Journal of Portfolio Management, vol. 26, pp. 27-31.

Kim, S. and In, F. 2002, 'The influence of foreign stock markets and macroeconomic news announcements on Australian financial markets', Pacific-Basin Finance Journal, vol. 10, pp. 571-82.

Li, J. and Born, J. A. 2006, 'Presidential election uncertainty and common stock returns in the United States', Journal of Financial Research, vol. 29, pp. 609-22.

Lim, K. P, Brooks, R. D. and Hinich, M. J. 2008, 'Nonlinear serial dependence and the weakform efficiency of Asian emerging stock markets', Journal of International Financial Markets, Institutions and Money, vol. 18, pp. 527-44.

Manning, D. N. 1989, 'The effect of political uncertainty on the stock market: The case of British Telecom', Applied Economics, vol. 21, pp. 881-89.

Mian, G. Mujtaba, A. and Christopher, M. 2001, Volatility dynamics in high frequency financial data: An empirical investigation of the Australian equity returns', Applied Financial Economics, vol. 11, pp. 341-52.

Niederhoffer, V. Gibbs, S. and Bullock, J. 1970, 'Presidential elections and the stock market', Financial Analysts Journal, Mar/Apr, pp. 111-13.

Peel, D. A. and Pope, P. F. 1983, 'General elections in the U.K. in the post 1950 period and the behaviour of the stock market', Investment Analyst, vol. 67, pp. 4-10.

Powell, J. G. Jing, S. Smith, T. and Whaley, R. E. 2007, 'The persistent presidential dummy: Differences turn out to be insignificant', Journal of Portfolio Management, vol. 33, pp. 133-43,

Riley, W. B. and Luksetich W. A. 1980, 'The market prefers Republicans: Myth or reality', Journal of Financial and Quantitative Analysis, vol. 15, pp. 541-60.

Santa-Clara, P. and Valkanov, R. 2003, 'The presidential puzzle: Political cycles and the stock market', Journal of Finance, vol. 58, pp. 1841-72

Thompson, R. S. and Ioannidis, C. 1987, 'The stock market response to voter opinion polls', Investment Analyst, vol. 83, pp. 19-22.

Worthington, A. C. 2006, 'Market risk in demutualized self-listed stock exchanges: An international analysis of selected time-varying betas', Global Economic Review, vol. 35, pp. 239-57.

Worthington, A. C. 2008, 'The impact of natural events and disasters on the Australian stock market: A GARCH-M analysis of storms, floods, cyclones, earthquakes and bushfires', Global Business and Economics Review, vol. 10, pp. 1-10. 
Table 1 Australian Ministries and Monthly Market Returns, January 1901 to December 2005

\begin{tabular}{|c|c|c|c|c|c|c|c|c|c|c|c|c|c|c|c|c|c|c|c|c|c|}
\hline No. & $\begin{array}{c}\text { Ministry by } \\
\text { prime minister }\end{array}$ & $\begin{array}{l}\text { Party or } \\
\text { coalition }\end{array}$ & & $\begin{array}{l}\text { Start } \\
\text { date }\end{array}$ & & $\begin{array}{l}\text { End } \\
\text { date }\end{array}$ & $\begin{array}{l}\text { Term } \\
\text { in } \\
\text { office }\end{array}$ & Return & $\begin{array}{c}\text { Excess } \\
\text { return } \\
\text { over } \\
\text { inflation } \\
\end{array}$ & $\begin{array}{c}\text { Excess } \\
\text { return } \\
\text { over } \\
\text { interest } \\
\end{array}$ & No. & $\begin{array}{r}\text { Min } \\
\text { prime }\end{array}$ & $\begin{array}{l}\text { Party or } \\
\text { coalition }\end{array}$ & & $\begin{array}{l}\text { Start } \\
\text { date }\end{array}$ & & $\begin{array}{l}\text { End } \\
\text { date }\end{array}$ & $\begin{array}{l}\text { Term } \\
\text { in } \\
\text { office }\end{array}$ & Return & $\begin{array}{c}\text { Excess } \\
\text { return } \\
\text { over } \\
\text { inflation } \\
\end{array}$ & $\begin{array}{c}\text { Excess } \\
\text { return } \\
\text { over } \\
\text { interest } \\
\end{array}$ \\
\hline 1 & arton & Non-Labor & Jan & 1901 & Sep & 1903 & 33 & 0.1648 & 0.0433 & - & 31 & Mer & Non-Labor & Jan & 1956 & Dec & c 1958 & 23 & 0.9110 & 0.7462 & 0.8277 \\
\hline 2 & eakin & Non-Labor & Sep & 1903 & Apr & 1904 & 7 & 1.3060 & 1.6479 & - & 32 & & & Dec & 1958 & Dec & c 1963 & 61 & & & \\
\hline 3 & Watson & Labor & Apr & 1904 & Aug & 1904 & 4 & 1.1946 & 1.6529 & - & 33 & Menz & Non-Labor & Dec & 1963 & Jan & 1966 & 25 & -0 & 575 & 389 \\
\hline 4 & Reid-McLean & Non-Labor & Aug & 1904 & Jul & 1905 & 10 & 0.5907 & 0.5310 & - & 34 & Holt & Non-Labor & Jan & 1966 & Dec & c 1966 & 10 & -0.3654 & 218 & 7471 \\
\hline 5 & Deakin & Non-Labor & Jul & 1905 & Nov & 1908 & 40 & 0.6270 & 0.4517 & - & 35 & Holt & Non-Labor & Dec & 1966 & Dec & C 1967 & 12 & 2.8128 & 2.5845 & 2.4395 \\
\hline 6 & isher & Labor & Nov & 1908 & Jun & 1909 & 7 & 0.4449 & 0.3009 & - & 36 & McEwen & Non-Labor & Dec & 1967 & Jan & 1968 & 1 & & .7730 & 0.6947 \\
\hline 7 & Deakin & Non-Labor & Jun & 1909 & Apr & 1910 & 11 & 0.6518 & 0.5855 & - & 37 & Gorton & Non-Labor & Jan & 1968 & Feb & 1968 & 2 & & 647 & 0.8497 \\
\hline 8 & isher & Labor & Apr & 1910 & Jun & 1913 & 38 & 0.2678 & -0.1501 & - & 38 & Gor & & Feb & 1968 & Nov & v 1969 & 20 & & & 0.8634 \\
\hline 9 & Cook & Non- & Jun & 1913 & Sep & 1914 & 15 & 0.2 & & - & 39 & Gor & & Nov & 1969 & Mar & r 1971 & 6 & & & 097 \\
\hline 10 & Fisher & Labor & Sep & 1914 & Oct & 1915 & 13 & 0.0 & -1 & - & 40 & Mcl & n-Labor & Mar & 1971 & Dec & C 1972 & 21 & 40 & 0.5313 & 6208 \\
\hline 11 & Huohe & Labor & Oct & 1915 & Nov & 1916 & 12 & -0. & -0.7 & - & 41 & & & Dec & 1972 & Dec & C 1972 & 1 & & -0.2193 & 1868 \\
\hline 12 & $\mathrm{Hu}$ & bor & Nov & 1916 & Feb & 1917 & 4 & -0.0 & 336 & - & 42 & & & Dec & 1972 & Jun & 1974 & 17 & & & 069 \\
\hline 13 & Hus & bor & Feb & 1917 & Jan & 1918 & 10 & 51 & 11 & - & 43 & Wh & & Jun & 1974 & Nov & v 1975 & 17 & & & -0.9147 \\
\hline 14 & Hug & or & Jan & 1918 & Feb & 1923 & 6 & & & - & 44 & Fraser & or & Nov & 1975 & Dec & C 1975 & 2 & & & 233 \\
\hline 15 & Bruc & Non- & Feb & 1923 & Oct & & 81 & & & & 45 & & & Dec & & Dec & c 1977 & 24 & & & \\
\hline 16 & Scullin & Labor & Oct & 1929 & Jan & 1932 & 26 & -1.4 & -0 . & -1.8972 & 46 & $\mathrm{Fr}$ & or & Dec & 1977 & Nov & v 1980 & 34 & 109 & 312 & 1.6484 \\
\hline 17 & Lyons & Non-Labor & Jan & 1932 & Nov & 1938 & 82 & 0.8421 & 0.7621 & 0.6512 & 47 & Fraser & bor & Nov & 1980 & May & у 1982 & 18 & & & -3.2398 \\
\hline 18 & Lyons & Non-Labor & Nov & 1938 & Apr & 1939 & 5 & -0.6098 & -0.9278 & -0.7556 & 48 & Fraser & n-Labor & May & 1982 & Mar & r 1983 & 10 & & & -1.2049 \\
\hline 19 & Page & Non-Labor & Apr & · 1939 & Apr & 1939 & 1 & -2.3546 & -2.3179 & -2.5004 & 49 & Hawke & & Mar & 1983 & Dec & C 1984 & 1 & & 98 & 1.0421 \\
\hline 20 & Menz & & Apr & 1939 & Mar & 1940 & 10 & & & & 50 & & & Dec & 1984 & Jul & 19 & 2 & & & 1.8613 \\
\hline 21 & IVientz & bor & Mar & 1940 & Oct & 1940 & 8 & & & -0.7673 & 51 & & & Jur & 1987 & Apr & r 1990 & 32 & -0.8725 & & -2.0415 \\
\hline 22 & Menzies & Non-Labor & Oct & 1940 & Aug & 1941 & 10 & -0.0031 & -0.3971 & -0.1282 & 52 & Hawke & or & Apr & 1990 & Dec & c 1991 & 21 & 0.3457 & 0.0367 & -0.6141 \\
\hline 23 & Fadden & Non-Labor & Aug & 1941 & Oct & 1941 & 1 & 2.4532 & 2.1432 & 2.3282 & 53 & Keating & Labor & Dec & 1991 & Dec & c 1991 & 1 & -1.7532 & -1.7532 & -2.3782 \\
\hline 24 & Curtin & Labor & Oct & 1941 & Sep & 1943 & 24 & 0.1583 & -0.3280 & 0.0333 & 54 & Keating & & Dec & 1991 & Mar & r 1993 & 14 & 0.1941 & 0.1077 & -0.3048 \\
\hline 25 & Curtin & $x$ & Sep & 1943 & Jul & 1945 & 21 & 0.2633 & & 0.1620 & 55 & Kea & & Mar & 1993 & Mar & r 1996 & 35 & & & 0.3863 \\
\hline 26 & Forde & & Jul & & Jul & & 1 & & & & 56 & & & Mar & 1996 & Oct & 1998 & 2 & & & \\
\hline 27 & Chifley & Dent & Jul & 1945 & Nov & 1946 & 15 & 0.9726 & 0.4906 & 0.8893 & 57 & Howard & Non-Labor & Oct & 1998 & Nov & v 2001 & 37 & 0.5766 & .2891 & 0.1459 \\
\hline 28 & Chifley & Labor & Nov & 1946 & Dec & 1949 & 38 & 0.4341 & -0.2211 & 0.3551 & 58 & Howard & Non-Labor & Nov & 2001 & Oct & 2004 & 35 & 0.4128 & 0.2068 & 0.0045 \\
\hline 29 & Menzies & Non-L & Dec & 1949 & May & 1951 & 16 & 2.0631 & 0.9343 & 2.0006 & 59 & Howard & Non-Labor & Oct & 2004 & Dec & c 2005 & 14 & 1.5575 & 1.3241 & 1.0985 \\
\hline 30 & Menzies & Non-Labor & May & у 1951 & Jan & 1956 & 68 & -0.1591 & -0.7371 & -0.2382 & All & - & - & Jan & 1901 & Dec & c 2005 & 1260 & 0.4931 & 0.1565 & 0.0615 \\
\hline
\end{tabular}

Sources: Australian Electoral Commission (2008a, 2008b, 2008c). Notes: Return - mean monthly percentage return, Excess return over inflation - mean monthly excess percentage return minus monthly inflation, Excess return over interest - mean monthly excess percentage return minus monthly 3-month T-bill yield (since July 1928 only). Term in office is in months. The starting and ending date for each ministry is to the nearest non-overlapping month, i.e. if the previous ministry ended on 23 October (day-of-month not shown), that ministry ends in October and the following ministry starts in November. 
Figure 1 Mean Monthly Returns by Ministry, January 1901 to December 2005

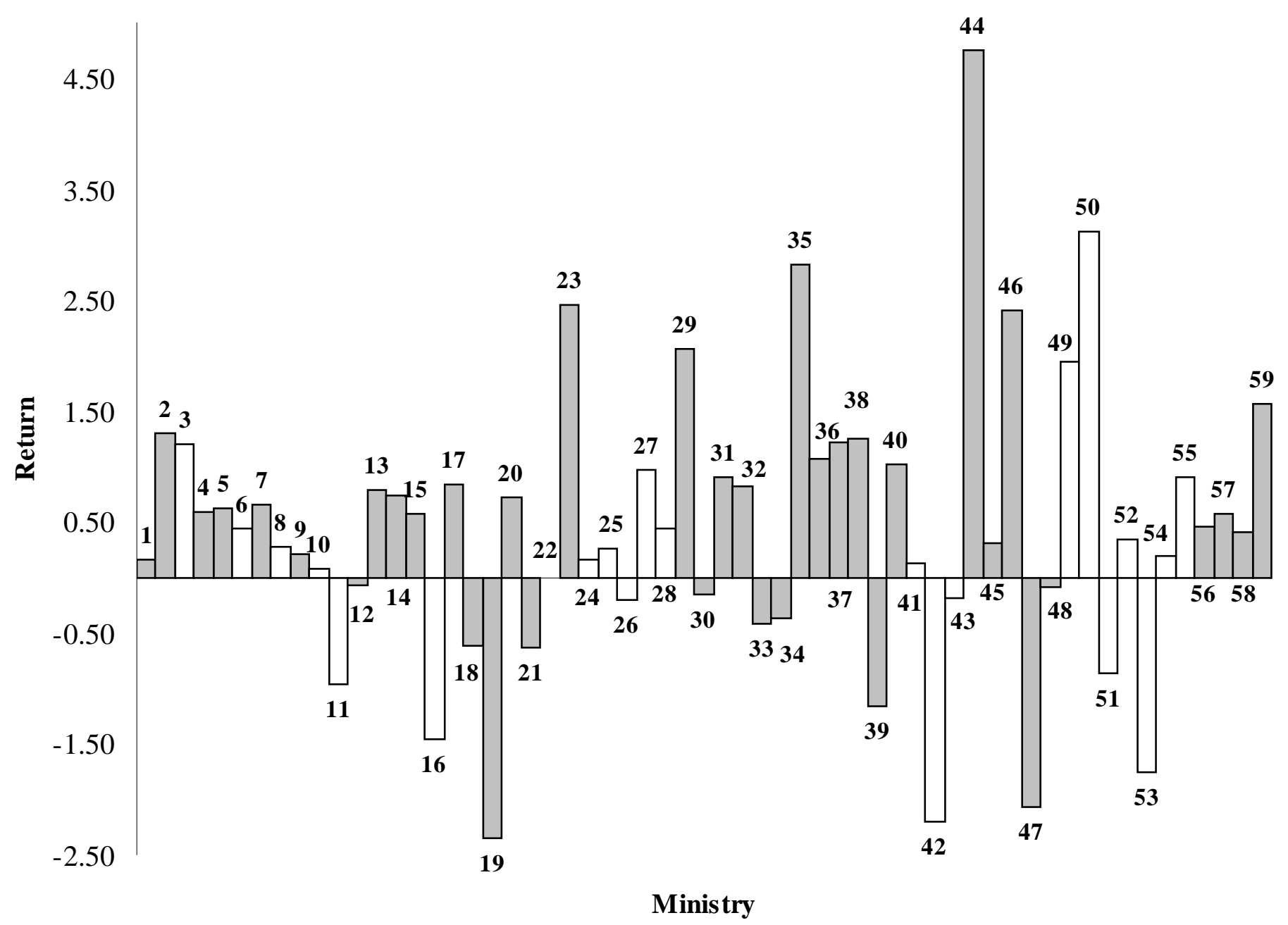

Notes: The numerical identifier for each ministry corresponds to Table 1 . Non-Labor ministries are shaded. The term in office varies by ministry. 
Table 2 Comparison of Monthly Returns, January 1901 to December 2005

\begin{tabular}{|c|c|c|c|c|}
\hline & Statistic & All & Non-Labor & Labor \\
\hline \multirow{10}{*}{ 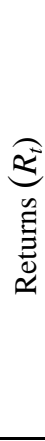 } & Number & 1258 & 869 & 389 \\
\hline & Mean & 0.495 & 0.574 & 0.312 \\
\hline & Median & 0.563 & 0.664 & 0.255 \\
\hline & Maximum & 20.105 & 16.723 & 20.105 \\
\hline & Minimum & -55.244 & -14.887 & -55.244 \\
\hline & Std. Dev. & 4.489 & 3.282 & 5.229 \\
\hline & Skewness & -2.100 & -0.120 & -3.042 \\
\hline & Kurtosis & 29.550 & 6.727 & 35.744 \\
\hline & Jarque-Bera & $2.8 \mathrm{E}+04$ & $5.0 \mathrm{E}+02$ & $1.8 \mathrm{E}+04$ \\
\hline & Probability & $<0.01$ & $<0.01$ & $<0.01$ \\
\hline \multirow{10}{*}{ 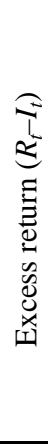 } & Number & 1258 & 869 & 389 \\
\hline & Mean & 0.156 & 0.269 & -0.095 \\
\hline & Median & 0.351 & 0.406 & 0.172 \\
\hline & Maximum & 21.452 & 15.973 & 21.452 \\
\hline & Minimum & -55.861 & -15.624 & -55.861 \\
\hline & Std. Dev. & 4.040 & 3.333 & 5.284 \\
\hline & Skewness & -2.245 & -0.241 & -3.030 \\
\hline & Kurtosis & 34.246 & 6.501 & 35.069 \\
\hline & Jarque-Bera & $5.2 \mathrm{E}+04$ & $4.5 E+02$ & $1.7 \mathrm{E}+04$ \\
\hline & Probability & $<0.01$ & $<0.01$ & $<0.01$ \\
\hline \multirow{10}{*}{ 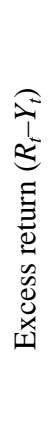 } & Number & 928 & 613 & 315 \\
\hline & Mean & 0.061 & 0.207 & -0.222 \\
\hline & Median & 0.236 & 0.381 & 0.059 \\
\hline & Maximum & 19.616 & 16.299 & 19.616 \\
\hline & Minimum & -56.193 & -15.757 & -56.193 \\
\hline & Std. Dev. & 4.502 & 3.734 & 5.704 \\
\hline & Skewness & -2.237 & -0.249 & -3.027 \\
\hline & Kurtosis & 30.209 & 5.615 & 32.043 \\
\hline & Jarque-Bera & $2.9 E+04$ & $1.8 \mathrm{E}+02$ & $1.1 \mathrm{E}+04$ \\
\hline & Probability & $<0.01$ & $<0.01$ & $<0.01$ \\
\hline
\end{tabular}

Notes: Levene's test of equality of variances by category (Labor and non-Labor) is rejected for returns (statistic $=$ 25.27, $p$-value $=<0.01$ ), excess returns over inflation (statistic $=25.30, p$-value $=<0.01$ ) and excess returns over interest (statistic $=13.54, p$-value $=<0.01$ ). A $t$-test for equality of means (Labor and non-Labor) fails to be rejected for returns (statistic $=0.91, p$-value $=0.36$ ), excess returns over inflation (statistic $=1.26, p$-value $=$ 0.21 ) and excess returns over interest (statistic $=1.21, p$ value $=0.23$ ). The critical value of significance for at least 315 observations is 0.138 for skewness and 0.270 for kurtosis. The sample period for excess returns over interest is from July 1928. 
Table 3 Estimated Political Cycle Models

\begin{tabular}{|c|c|c|c|c|c|c|c|c|c|c|c|}
\hline & & \multirow[b]{2}{*}{ Parameter } & \multicolumn{3}{|c|}{ Returns $\left(R_{t}\right)$} & \multicolumn{3}{|c|}{$\begin{array}{l}\text { Excess returns over } \\
\text { inflation }\left(R_{t}-I_{t}\right)\end{array}$} & \multicolumn{3}{|c|}{$\begin{array}{l}\text { Excess returns over } \\
\text { interest }\left(R_{t}-Y_{t}\right)\end{array}$} \\
\hline & & & Coefficient & Std. error & $p$-value & Coefficient & Std. error & $p$-value & Coefficient & Std. error & $p$-value \\
\hline \multirow{11}{*}{ 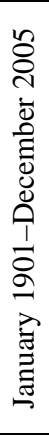 } & \multirow{5}{*}{ 氶 } & $\gamma_{0}$ & 0.004 & 0.008 & 0.61 & -0.002 & 0.008 & 0.81 & -0.003 & 0.009 & 0.67 \\
\hline & & $\alpha_{1}$ & 0.613 & 0.130 & $<0.01$ & 0.434 & 0.133 & $<0.01$ & 0.614 & 0.187 & $<0.01$ \\
\hline & & $\alpha_{2}$ & 0.359 & 0.150 & 0.02 & 0.177 & 0.157 & 0.25 & 0.357 & 0.222 & 0.10 \\
\hline & & $\alpha_{3}$ & -0.001 & 0.003 & 0.94 & 0.001 & 0.003 & 0.76 & -0.006 & 0.004 & 0.14 \\
\hline & & $\alpha_{4}$ & 0.487 & 0.292 & 0.09 & 0.439 & 0.291 & 0.13 & 0.938 & 0.435 & 0.03 \\
\hline & \multirow{6}{*}{ 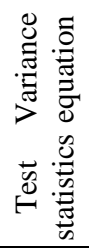 } & $\beta_{0}$ & 0.174 & 0.062 & $<0.01$ & 0.214 & 0.073 & $<0.01$ & 0.314 & 0.117 & $<0.01$ \\
\hline & & $\beta_{1}$ & 0.201 & 0.031 & $<0.01$ & 0.217 & 0.032 & $<0.01$ & 0.237 & 0.040 & $<0.01$ \\
\hline & & $\gamma_{1}$ & 0.814 & 0.023 & $<0.01$ & 0.801 & 0.023 & $<0.01$ & 0.786 & 0.028 & $<0.01$ \\
\hline & & ARCH-LM & 1.080 & - & 0.37 & 0.764 & - & 0.68 & 0.509 & - & 0.90 \\
\hline & & $\alpha_{1}+\alpha_{2 . .}=0$ & 52.484 & - & $<0.01$ & 8.731 & - & $<0.01$ & 17.734 & - & $<0.01$ \\
\hline & & $\alpha_{1}=\alpha_{2}$ & 2.773 & - & 0.04 & 2.558 & - & 0.11 & 1.370 & - & 0.12 \\
\hline \multirow{11}{*}{ 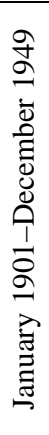 } & \multirow{4}{*}{ 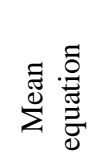 } & $\gamma_{0}$ & -0.004 & 0.020 & 0.82 & -0.003 & 0.020 & 0.85 & 0.002 & 0.013 & 0.83 \\
\hline & & $\alpha_{1}$ & 0.575 & 0.156 & $<0.01$ & 0.396 & 0.166 & 0.01 & 0.406 & 0.298 & 0.17 \\
\hline & & $\alpha_{2}$ & 0.321 & 0.165 & 0.05 & 0.116 & 0.177 & 0.51 & 0.209 & 0.170 & 0.22 \\
\hline & & $\alpha_{3}$ & 0.001 & 0.003 & 0.71 & 0.002 & 0.003 & 0.53 & -0.005 & 0.005 & 0.29 \\
\hline & \multirow{7}{*}{ 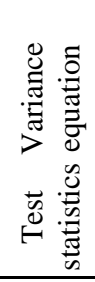 } & $\alpha_{4}$ & 0.047 & 0.316 & 0.88 & -0.013 & 0.308 & 0.96 & 0.633 & 0.462 & 0.17 \\
\hline & & $\beta_{0}$ & 0.346 & 0.136 & 0.01 & 0.343 & 0.141 & 0.01 & 0.160 & 0.112 & 0.15 \\
\hline & & $\beta_{1}$ & 0.250 & 0.062 & $<0.01$ & 0.216 & 0.054 & $<0.01$ & 0.570 & 0.209 & $<0.01$ \\
\hline & & $\gamma_{1}$ & 0.729 & 0.056 & $<0.01$ & 0.762 & 0.052 & $<0.01$ & 0.646 & 0.071 & $<0.01$ \\
\hline & & ARCH-LM & 14.658 & - & $<0.01$ & 0.860 & - & 0.58 & 7.859 & - & $<0.01$ \\
\hline & & $\alpha_{1}+\alpha_{2 . .}=0$ & 24.540 & - & $<0.01$ & 1.552 & - & 0.21 & 5.196 & - & 0.26 \\
\hline & & $\alpha_{1}=\alpha_{2}$ & 2.380 & - & 0.0614 & 2.582 & - & 0.10 & 0.500 & - & 0.23 \\
\hline \multirow{11}{*}{ 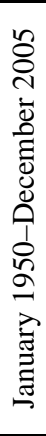 } & \multirow{4}{*}{ 胥 } & $\gamma_{0}$ & -0.004 & 0.014 & 0.7743 & -0.009 & 0.014 & 0.51 & -0.009 & 0.014 & 0.50 \\
\hline & & $\alpha_{1}$ & 0.877 & 0.296 & 0.0031 & 0.591 & 0.301 & 0.04 & 0.569 & 0.300 & 0.05 \\
\hline & & $\alpha_{2}$ & 1.185 & 0.504 & 0.0188 & 0.910 & 0.489 & 0.06 & 0.504 & 0.508 & 0.32 \\
\hline & & $\alpha_{3}$ & -0.006 & 0.009 & 0.4744 & -0.003 & 0.009 & 0.69 & -0.003 & 0.009 & 0.71 \\
\hline & \multirow{7}{*}{ 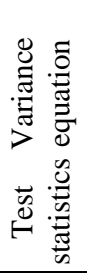 } & $\alpha_{4}$ & 1.577 & 0.904 & 0.0811 & 1.410 & 0.913 & 0.12 & 1.595 & 0.917 & 0.08 \\
\hline & & $\beta_{0}$ & 0.632 & 0.281 & 0.0243 & 0.872 & 0.371 & 0.01 & 0.544 & 0.253 & 0.03 \\
\hline & & $\beta_{1}$ & 0.147 & 0.035 & $<0.01$ & 0.176 & 0.041 & $<0.01$ & 0.127 & 0.032 & $<0.01$ \\
\hline & & $\gamma_{1}$ & 0.833 & 0.033 & $<0.01$ & 0.798 & 0.038 & $<0.01$ & 0.854 & 0.031 & $<0.01$ \\
\hline & & ARCH-LM & 0.298 & - & 0.9896 & 0.266 & - & 0.99 & 0.280 & - & 0.99 \\
\hline & & $\alpha_{1}+\alpha_{2 . .}=0$ & 20.076 & - & $<0.01$ & 6.634 & - & 0.01 & 12.159 & - & 0.01 \\
\hline & & $\alpha_{1}=\alpha_{2}$ & -0.598 & - & 0.2196 & 0.672 & - & 0.41 & 0.026 & - & 0.43 \\
\hline
\end{tabular}

Notes: Dependent variables are returns, excess returns over inflation and excess returns over interest in percentages. The GARCH$\mathrm{M}$ models include the conditional variance in the mean equation $\left(\gamma_{0}\right)$ along with dummy variables for non-Labor $\left(\alpha_{1}\right)$ and Labor $\left(\alpha_{2}\right)$ ministries, a ministerial political cycle trend $\left(\alpha_{3}\right)$ and a dummy variable for election months $\left(\alpha_{4}\right)$. The variance equation includes a constant $\left(\beta_{0}\right)$, a first-order autoregressive ARCH term $\left(\beta_{1}\right)$ and a first-order moving average GARCH term $\left(\gamma_{1}\right)$. ARCH test - Lagrange multiplier test of null hypothesis of no ARCH errors versus the alternative hypothesis that the conditional error variance is given by an $\mathrm{ARCH}(12)$ process from a least squares regression. The sub-sample periods for excess returns over interest are July 1928-December 1949 and January 1950-December 2005. 